\title{
PENGEMBANGAN HAIR TONIK KOMBINASI EKSTRAK ETANOL DAUN PANDAN WANGI DAN DAUN LIDAH MERTUA
}

\author{
${ }^{1}$ Gina Septiani A., ${ }^{2}$ Anny Victor Purba, \& ${ }^{3}$ Agung Eru W. \\ ${ }^{1,2}$ Staf Dosen Prodi Magister Fakultas Farmasi Universitas Pancasila Jakarta, 12640 \\ ${ }^{3}$ BPPT Puspitek Serpong, LAPTIAB, PUSPIPTEK, Serpong, 15314 \\ e-mail: ginaagustien@yahoo.co.id
}

\begin{abstract}
Abstrak
Tujuan penelitian ini untuk memperoleh sediaan kombinasi ekstrak daun pandan wangi (Pandanus amaryllifolius Roxb) dan daun lidah mertua (Sansevieria trifasciata Prain) dalam bentuk sediaan tonik rambut. Sediaan uji dibuat dengan mengkombinasikan kedua ekstrak pada konsentrasi $5 \%$ dengan perbandingan ekstrak daun pandan wangi dan daun lidah mertua 1:1, 2:3 dan 3:2. Hasil menunjukkan bahwa kombinasi ekstrak daun pandan wangi dan daun lidah mertua dengan kombinasi 3:2 memiliki aktivitas pertumbuhan rambut yang paling baik dan selanjutnya dibuat sediaan tonik rambut. Dalam pengujian aktivitas pertumbuhan rambut ini sediaan tonik ekstrak kombinasi 3:2 dibandingkan dengan basis tonik rambut, kontrol normal dan minoxidil $5 \%$. Hasil uji aktivitas menunjukkan bahwa tonik rambut mempunyai aktivitas yang tidak berbeda dengan kontrol positif pada minggu ke 3 dan ke 4 . Uji stabiitas secara fisik dilakukan selama 3 bulan pada suhu $2 \pm 2{ }^{\circ} \mathrm{C}, 25 \pm 2{ }^{\circ} \mathrm{C}$ dan $40 \pm 2{ }^{\circ} \mathrm{C}$. Uji iritasi akut dermal diketahui bahwa ekstrak tunggal daun pandan wangi dan daun lidah mertua masing-masing indeks iritan ringan $(0,5-1,9)$, sedangkan ekstrak, sediaan tonik dan basis tonik mempunyai indeks iritasi sangat ringan $(0,0-0,04)$. Hasil uji cemaran mikroba dengan Metode Angka Lempeng Total memenuhi persyaratan sediaan kosmetik koloni $<10^{5}$.
\end{abstract}

Kata kunci: hair tonik, aktivitas pertumbuhan rambut, pandanus amaryllifolius, sansevieria trifasciata.

\begin{abstract}
The purpose of this study was to obtain a combination preparation of pandan leaves extract (Pandanus amaryllifolius Roxb.) and sansevieria leaves (Sansevieria trifasciata Prain.) in the form of hair tonic. The preparation test was made by combining both extracts in concentration of $5 \%$ with the ratio ware of pandan leaves extract and sansevieria leaves 1:1, 2:3 and 3:2. The results showed that the combination of pandan leaves extract and sansevieria leaves with 3:2 combination had the best hair growth activity and furthermore the best result of extract activity of the test preparation was hair tonic. Hair tonic was tasted the activity in accelerating hair growth compared 3:2 with hair tonic base, normal control and minoxidil 5\%. The results of the activity test show that the hair tonic has activity that is not different from the positive control at week 3 and 4 . Physical stability test is done for 3 months at $2 \pm 2{ }^{\circ} \mathrm{C}, 25 \pm 2{ }^{\circ} \mathrm{C}$ dan $40 \pm 2{ }^{\circ} \mathrm{C}$. The dermal acute irritation test showed that the single extract of pandan leaves and sansevieria leaves has a mild irritant index $(0,5-1,9)$, while the extract, tonic and tonic base had very mild irritation index $(0.0-0,04)$. The test result of with Method of Total Plate Count showed that the number of colony microbial contamination is 0 colony $/ \mathrm{ml}$, so that it meets the requirements of the colony cosmetic preparation $<10^{5}$.
\end{abstract}

Keywords: hair tonic, hair growth activity, pandanus amaryllifolius, sansevieria trifasciata. 


\section{PENDAHULUAN}

Masalah kerontokan mempengaruhi sebagian besar jumlah persentasi penduduk yang melakukan pengobatan ke dokter kulit. Frekuensi dan kuantitas masalah rambut rontok ini meningkat akhirnya menyebabkan terjadinya kebotakan (Harrison dan Bergfeld, 2009) Penyebabnya beraneka ragam yaitu akibat penyakit sistemik, gangguan hormonal, stres, makanan yang dikonsumsi, kelainan genetik, stimulus dari lingkungan, maupun kosmetik rambut (Noruka,2005) (Mitsui,1996). Produk kosmetik untuk memecahkan masalah rambut rontok banyak dikembangkan (Lucky, 2004), berasal dari produk-produk sintetis. Namun obat sintetis seperti minoxidil, berpotensi menyebabkan efek samping (Mannion,1998).

Salah satu tanaman yang secara empiris dapat dimanfaatkan sebagai perawatan rambut adalah daun pandan wangi (Mannion, 2013). Tanaman lainnya yaitu lidah mertu yang mengandung flavonoid, glikosida, saponin, tanin dan polifenol (Hariana, 2013). Pencapaian kerja sinergi dari produk tanaman obat diharapkan dapat dilakukan dengan mengkombinasi beberapa tanaman. Bentuk sediaan hair tonik dipilih karena sediaan ini cocok untuk penggunaan topikal pada rambut, karena lebih mudah pengaplikasiannya dan tidak lengket dibandingkan dengan sediaan semisolid (Tranggono dan Latifah, 2007).

Penelitian ekstrak daun pandan wangi dan daun lidah mertua ini dikombinasikan dalam bentuk sediaan hair tonik dengan tujuan digunakan sebagai zat aktif untuk meningkatkan pertumbuhan rambut.

\section{METODE PENELITIAN}

Bahan yang digunakan adalah daun pandan wangi dan daun lidah mertua; minoxidil; etanol 96\%; propilen glikol; tween 80; metil paraben; $\mathrm{Na}_{2} \mathrm{EDTA}$; mentol; sodium metabisulfit (Brataco); aquadest; pereaksi-pereaksi untuk skrining fitokimia.

Penelitian ini menggunakan alat timbangan analitik (Excelent® Model HZY
A200); Rotary evaporator; moisture analyzer (Simadzu $\circledast$ ); $\quad$ pH-meter, Viscometer Brookfield (DV1-Prime®); homogenizer (IKA® RW 20 Digital).

Serbuk simplisia ditimbang sebanyak 700 gram, dilakukan secara bertahap dengan merendam serbuk simplisia 100 gram dalam 1 liter etanol $70 \%$ selama 2 hari, diaduk setiap 6 jam sekali kemudian disaring menggunakan kain flannel. Filtrat dipekatkan dengan rotary evaporator pada suhu $50^{\circ} \mathrm{C}$, lalu ekstrak dikentalkan dengan cara dipanaskan di atas penangas air hingga pelarut menguap (Ditjen POM, 2000)

Uji aktivitas ekstrak terhadap pertumbuhan rambut menggunakan satu metode pencukuran, punggung kelinci dihilangkan rambutnya dengan cara dicukur sampai bersih kemudian dibagi menjadi 6 petak dengan ukuran $2 \times 2 \mathrm{~cm}$ dan jarak antar petak $1 \mathrm{~cm}$. Setelah pencukuran dan sebelum dilakukan pengolesan, punggung kelinci untuk daerah perlakuan diolesi etanol $70 \%$ sebagai antiseptik. Bagian-bagian daerah tersebut adalah:

P1 : Tidak diolesi apapun

P2 : Ekstrak daun pandan wangi 5\%

P3 : Ekstrak daun lidah mertua 5\%

P4 : Kombinasi ekstrak 5\% dengan perbandingan daun pandan wangi dan daun lidah mertua 1:1

P5: Kombinasi ekstrak 5\% dengan perbandingan daun pandan wangi dan daun lidah mertua 2:3

P6 : Kombinasi ekstrak 5\% dengan perbandingan daun pandan wangi dan daun lidah mertua 3:2

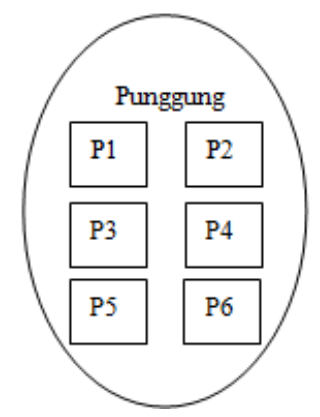

Gambar 1. Denah perlakuan uji ekstrak pada punggung kelinci 
Pengolesan dilakukan setiap hari yaitu pada pagi dan sore hari dengan volume sebanyak $1 \mathrm{~mL}$ selama 28 hari. Pengamatan dilakukan dengan mengambil 10 helai rambut kelinci pada tiap bagian setiap 7 hari sekali. Pengukuran selanjutnya dilakukan pada hari ke-14, ke-21, dan ke-28 (Tanaka dkk, 1980) Hasil dengan aktivitas pertumbuhan rambut terbaik selanjutnya dibuat formulasi tonik rambut dan dilakukan uji stabilitas dan aktivitas sediaan hair tonik. Nomor surat kode etik uji hewan yaitu : No.201/Kep/IV/2017.

Tabel 1. Formula basis sediaan hair tonik

\begin{tabular}{lc}
\hline \multicolumn{1}{c}{ Bahan } & Konsentrasi (\%) \\
\hline Etanol 96\% & 30 \\
\hline Propilen glikol & 10 \\
\hline Tween 80 & 1,00 \\
\hline Metil paraben & 0,075 \\
\hline Na2EDTA & 0,025 \\
\hline Mentol & 0,100 \\
\hline Sodium metabisulfit & 0,200 \\
\hline Aquadest & Add 100 \\
\hline
\end{tabular}

\section{Uji Stabilitas Sediaan}

Sediaan hair tonik dievaluasi setiap 15 hari sekali meliputi pengamatan organoleptik, uji homogenitas, uji $\mathrm{pH}$, viskositas dan densitas. Dilakukan pada sediaan yang disimpan pada suhu $4^{\circ} \mathrm{C} \pm 2^{\circ} \mathrm{C}$ selama 3 bulan, dan suhu kamar $\left(25^{\circ} \mathrm{C} \pm\right.$ $2^{\circ} \mathrm{C}$ ) selama 3 bulan dan suhu $40^{\circ} \mathrm{C} \pm 2^{\circ} \mathrm{C}$ selama 1 bulan.

\section{Uji Aktivitas Sediaan Hair Tonik Terhadap Pertumbuhan Rambut}

Sediaan tonik rambut yang sudah dibuat dibandingkan dengan kontrol positif dan kontrol normal.

Bagian-bagian daerah tersebut adalah:

P1 : Formula hair tonik tanpa ekstrak

P2 : Tidak diolesi apapun

P3 : Formula hair tonik ekstrak

P4 : Sediaan hair tonik kontrol positif

Pengolesan dilakukan setiap hari pada pagi dan sore hari dengan volume sebanyak $1 \mathrm{~mL}$ selama 28 hari. Hari pertama pengolesan dianggap hari ke-0. Mulai hari ke ketujuh masing-masing daerah pelakuan dicukur bulunya sebanyak 10 helai rambut. Pengukuran selanjutnya dilakukan pada hari ke-14, ke-21 dan ke-28. Pada hari ke-28 dilakukan uji kelebatan rambut dengan mencukur rambut dengan luas 1 $\mathrm{cm}^{2}$ kemudian rambut tersebut ditimbang $\left(\mathrm{gram} / \mathrm{cm}^{2}\right)$

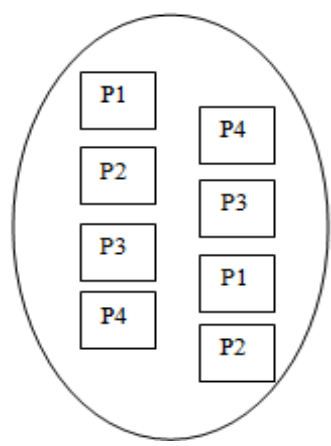

Gambar 2. Denah perlakuan uji sediaan hair tonik pada punggung kelinci

\section{Uji Keamanan (Iritasi) Untuk Produk Kosmetik}

Uji iritasi untuk eksrak kombinasi dilakukan dengan menimbang masingmasing ekstrak sebanyak 1,5 gram kemudian dicampurkan dengan bantuan ethanol $96 \%$ selanjutnya diambil 0,5 gram untuk dioleskan pada kulit kelinci. Semua hewan uji harus diamati ada tidaknya eritema dan udema, penilaian respon dilakukan pada jam ke 1, 24, 48, dan 72 jam (BPOM, 2014)

\section{Uji Mikrobiologi Sediaan}

Persyaratan cemaran mikroba pada kosmetika sediaan hair tonik menurut keputusan direktur jenderal pengawasan obat dan makanan Depkes RI Nomor: Hk. 00.06.4.02894 bahwa tidak boleh memiliki jumlah koloni angka lempeng total melebihi $10^{5} \mathrm{koloni} /$ gram (BPOM,20014).

\section{HASIL DAN PEMBAHASAN}

Ekstrak etanol daun pandan wangi yang dihasilkan adalah ekstrak kental berwarna hijau pekat, seberat 96,7 gram dengan rendemen $13,82 \%$. Sedangkan daun lidah mertua menghasilkan ekstrak 
kental berwarna coklat kekuningan dengan berat 121,3 dengan $17,33 \%$.

\section{Uji Aktivitas Ekstrak Terhadap Pertumbuhan Rambut}

Tabel 2. Hasil rata-rata panjang rambut kelinci tiap minggu

\begin{tabular}{lcccc}
\hline \multirow{2}{*}{ Perlakuan } & \multicolumn{4}{c}{ Rata-rata panjang (mm) } \\
\cline { 2 - 5 } & $\mathbf{4}$ & $\mathbf{2}$ & $\mathbf{3}$ & $\mathbf{4}$ \\
\cline { 2 - 5 } & 1,5 & 1,7 & 2,1 & 3,1 \\
\hline Kontrol normal & 2,3 & 2,4 & 4,1 & 6,2 \\
\hline $\begin{array}{l}\text { Ekstrak Daun } \\
\text { Lidah Mertua 5\% }\end{array}$ & 2,4 & 2,7 & 5,4 & 8,1 \\
\hline $\begin{array}{l}\text { Ekstrak Pandan } \\
\text { Wangi 5\% }\end{array}$ & 2,6 & 3,6 & 7,2 & 10,3 \\
\hline $\begin{array}{l}\text { Ekstrak kombinasi } \\
\text { 5\% (1:1) }\end{array}$ & 3,5 & 5,9 & 9,0 & 13,6 \\
\hline $\begin{array}{l}\text { Ekstrak kombinasi } \\
\text { 5\% (2PW:3LM) }\end{array}$ & 5,5 & 9,7 & 12,3 & 15,9 \\
\hline $\begin{array}{l}\text { Ekstrak kombinasi } \\
\text { 5\% (3PW:2LM) }\end{array}$ & & & & \\
\hline
\end{tabular}

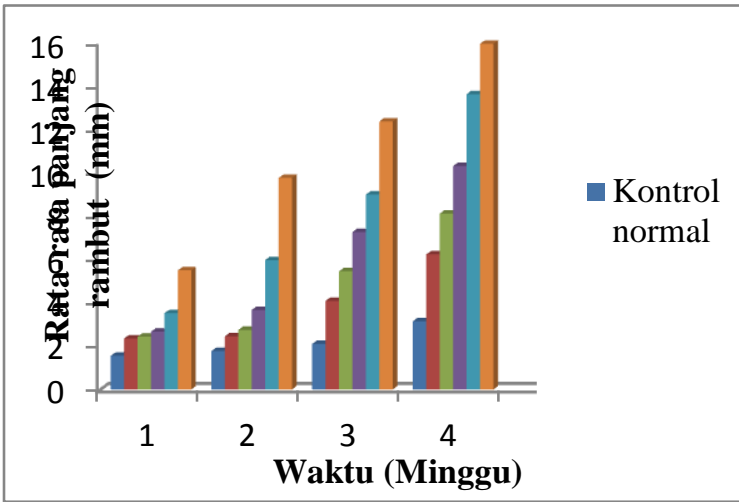

Gambar 3. Grafik rata-rata panjang rambut kelinci tiap minggu pada

uji aktivitas ekstrak

Berdasarkan data tersebut terjadi peningkatan rata-rata pertumbuhan rambut pada kelompok perlakuan dibandingkan dengan kontrol normal. Diperoleh data ratarata rambut tiap minggu menunjukkan bahwa ekstrak kombinasi memiliki aktivitas pertumbuhan rambut lebih baik dibandingkan dengan ekstrak tunggal untuk tiap minggunya.

\section{Evaluasi Sediaan Tonik Rambut}

Konsentrasi ekstrak yang dibuat untuk sediaan tonik rambut adalah ekstrak kombinasi ekstrak daun pandan wangi dan daun lidah mertua (3:2).

Tabel 3. Karakteristik dan hasil uji stabilitas sediaan tonik rambut

\begin{tabular}{lc}
\hline \multicolumn{1}{c}{ Warna } & $\begin{array}{c}\text { Hijau } \\
\text { kekuningan }\end{array}$ \\
\hline Bau & Khas \\
\hline Kejernihan & Jernih \\
\hline Homogentitas & Homogen \\
\hline $\mathrm{Ph}$ & 6,15 \\
\hline Berat jenis & $1,54 \mathrm{gram} / \mathrm{ml}$ \\
\hline Viskositas & $10,4 \mathrm{Cp}$ \\
\hline
\end{tabular}

Uji Aktivitas Sediaan Tonik Rambut Terhadap Pertumbuhan Rambut

Pada uji aktivitas pertumbuhan rambut dengan mengamati dua parameter uji yaitu rata-rata panjang rambut dan bobot rambut kelinci selama 28 hari. Perhitungan rata-rata panjang rambut kelinci diamati setiap seminggu sekali.

Tabel 4. Hasil rata-rata panjang rambut tiap perlakuan per minggu

\begin{tabular}{lcccc}
\hline \multirow{2}{*}{ Perlakuan } & \multicolumn{4}{c}{ Rata-rata panjang (mm) } \\
\cline { 2 - 5 } & \multicolumn{4}{c}{ Minggu ke- } \\
\cline { 2 - 5 } & $\mathbf{1}$ & $\mathbf{3}$ & $\mathbf{4}$ \\
\hline $\begin{array}{l}\text { Kontrol } \\
\text { normal }\end{array}$ & 1,42 & 1,72 & 2,08 & 3,13 \\
\hline Basis & 1,47 & 1,77 & 2,12 & 3,34 \\
\hline $\begin{array}{l}\text { Tonik } \\
\text { rambut }\end{array}$ & 4,32 & 7,39 & 10,62 & 12,02 \\
\hline $\begin{array}{l}\text { Kontrol } \\
\text { positif }\end{array}$ & 5,20 & 8,68 & 11,06 & 12,95 \\
\hline
\end{tabular}

Berdasarkan data tersebut terjadi peningkatan rata-rata pertumbuhan rambut pada semua kelompok perlakuan dibandingkan dengan kontrol normal. Peningkatan pertumbuhan terbesar terjadi pada kelompok tonik rambut dengan ratarata panjang rambut $12,02 \mathrm{~mm}$ dan kontrol positif $12,95 \mathrm{~mm}$. Pertumbuhan rambut yang 
paling baik pada kelompok tonik rambut dan kontrol positif dibandingkan dengan kelompok normal dan kelompok basis, tetapi antar kelompok tonik rambut dan kelompok kontrol positif terhadap perbedaan bermakna dalam pertumbuhan rambut. Bobot rambut juga diamati pada minggu keempat.

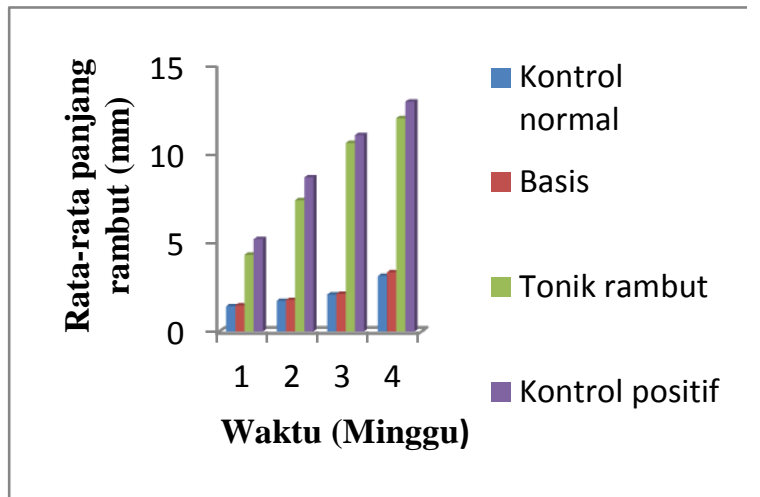

Gambar 4. Grafik rata-rata panjang rambut kelinci tiap minggu pada uji aktivitas hair tonik.

Tabel 5. Hasil bobot rata-rata rambut kelinci pada minggu ke-4

\begin{tabular}{lc}
\hline Perlakuan & Rata-rata $(\mathbf{m g}) \pm$ SD \\
\hline Kontrol normal & $16,8050 \pm 0,6165$ \\
\hline Basis & $17,1775 \pm 0,7578$ \\
\hline Tonik rambut & $90,9500 \pm 1,7423$ \\
\hline Kontrol positif & $94,2200 \pm 1,5205$ \\
\hline
\end{tabular}

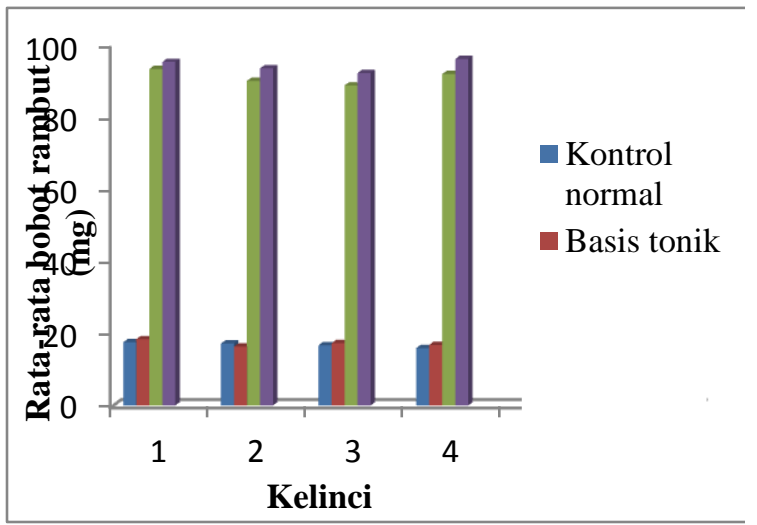

Gambar 5. Grafik rata-rata bobot rambut pada uji aktivitas hair tonik.
Hasil uji bobot rambut menunjukkan Kelompok tonik rambut seberat $90,95 \mathrm{mg}$ dan kontrol positif $94,22 \mathrm{mg}$ yang memberikan kelebatan rambut lebih baik dibandingkan dengan kelompok normal dan basis.

\section{Uji Iritasi Akut Dermal}

Hasil pengamatan dan perhitungan indeks iritasi pada hair tonik ekstrak kombinasi daun pandan wangi (3:2) menunjukkan iritasi sangat ringan (rentang $0-1,4)$. Sedangkan indeks iritasi pada tonik rambut dan basis setelah uji stabilitas, indeks nilai iritasi menunjukkan iritasi sangat ringan (rentang 0-0,4).

\section{Uji Mikrobiologi Angka Lempeng Total (ALT)}

Hasil pengujian angka lempeng total sediaan tonik rambut menunjukkan bahwa jumlah angka lempeng total bakteri untuk sediaan hair tonik adalah $0 \mathrm{koloni} / \mathrm{ml}$ yang berarti bahwa hasil pengujian sampel, memenuhi persyaratan cemaran mikroba pada kosmetika maksimum berjumlah $10^{5}$ koloni.

\section{KESIMPULAN}

Kombinasi ekstrak daun pandan wangi dan daun lidah mertua (3:2) memiliki aktivitas pertumbuhan rambut yang paling baik dibanding ekstrak tunggalnya. Sediaan ekstrak kombinasi hair tonik efektif sebagai penyubur rambut dengan rata-rata panjang rambut pada hari ke-28 sebesar $12,02 \mathrm{~mm}$ dan bobot rambut yaitu $90,95 \mathrm{mg}$. Sediaan hair tonik kombinasi memenuhi syarat mutu kimia, fisika dan keamanan dengan karakteristik sediaan hair tonik berwarna hijau kekuningan, homogen, bobot jenis $1,54 \mathrm{~g} / \mathrm{ml}$, viskositas $10,4 \mathrm{Cp}, \mathrm{pH} 6,15$, uji iritasi sangat ringan (0-0,4) dan angka lempeng total $<10^{5}$ koloni.

\section{DAFTAR PUSTAKA}

Djajadisastra J., (2004). Cosmetic Stability. Seminar Setengah Hari HIKI. Depok:

Departemen Farmasi Fakultas

Matematika dan IImu Pengetahuan Alam Universitas Indonesia. 
Lucky A.W., Piacquadio D.J., Ditre C.M., Dunlap F., Kantor I., Pandya A.G., et al, (2004). A randomized, placebo-controlled trial of $5 \%$ and $2 \%$ topical minoxidil solutions in the treatment of female pattern hair loss. J Am Acad Dermatol pp 541-53.

Mannion M., (1998). Nutraceutical revoultion continues at Foundation for Innovation in Medicine Conference. Am J Nat Med, pp 5:3.

Badan Pengawas Obat dan Makanan Republik Indonesia, (2004). Monografi Ekstrak Tumbuhan Obat Indonesia. Volume 1. Depkes, Jakarta

Beerling J., (2013). Plant from Asia \& Beyond as a Source of Active Ingredients for Modern High Performance Natural Cosmetics. Depok: Organic Monitor Ltd.

BPOM Peraturan Kepala Badan Pengawas Obat dan Makanan Republik Indonesia, (2014), Nomor 7 Tentang Pedoman Uji Toksisitas Nonklinik Secara In Vivo.

Ditjen POM., (2000). Parameter Standar Umum Ekstrak Tumbuhan Obat. Jakarta: Departemen Kesehatan Republik Indonesia.

Hariana A,, (2013). Tumbuhan Obat dan Khasiatnya. Penebar Swadaya. Jakarta.

Harrison S,, Bergfeld W,, (2009). Diffuse hair loss: its triggers and management. Clev Clin J Med.

Mitsui, (1996) New Cosmetic Science, Part II, Hair Cosmetics, Elsevier, Amsterdam. Netherlands. pp. 412-416.

Noruka N,E,, (2005). Hair loss: is there a relationship with hair care practices in Nigeria. International Journal of Dermatology.

Tanaka S,, Saito M,, and Tabata M., (1980). Bioassay of Crude Drugs for Hair Growth Promoting Activity in Mice by a New Simple Method. Journal of Medicinal Plant Research.

Tranggono, L., (2007). Buku Pegangan IImu Pengetahuan Kosmetik. Gramedia Pustaka umum. Jakarta. 